\title{
Correction to: Naturally occurring cell adhesion inhibitors
}

\section{Satoshi Takamatsu' ${ }^{1}$}

Published online: 3 August 2018

(C) The Author(s) 2018

\section{Correction to: Journal of Natural Medicines https://doi.org/10.1007/s11418-018-1220-z}

The article Naturally occurring cell adhesion inhibitors, written by Satoshi Takamatsu, was originally published electronically on the publisher's internet portal (currently SpringerLink) on 19 May 2018 without open access. With the author(s)' decision to opt for Open Choice the copyright of the article changed on 2 August 2018 to $($ C) The Author(s) 2018 and the article is forthwith distributed under the terms of the Creative Commons Attribution 4.0 International License (http://creativecommons.org/licenses/by/4.0/), which permits use, duplication, adaptation, distribution and reproduction in any medium or format, as long as you give appropriate credit to the original author(s) and the source, provide a link to the Creative Commons license and indicate if changes were made.

The original article was corrected.

Open Access This article is distributed under the terms of the Creative Commons Attribution 4.0 International License (http://creativeco mmons.org/licenses/by/4.0/), which permits unrestricted use, distribution, and reproduction in any medium, provided you give appropriate credit to the original author(s) and the source, provide a link to the Creative Commons license, and indicate if changes were made.
The original article can be found online at https://doi.org/10.1007/ s11418-018-1220-z.

Satoshi Takamatsu stakamat@pharm.showa-u.ac.jp

1 Division of Natural Medicine and Therapeutics, Department of Clinical Pharmacy, School of Pharmacy, Showa University, 1-5-8 Hatanodai, Shinagawa-ku, Tokyo 142-8555, Japan 